On the other hand, if the antigen was composed of a total protein extract from a non-ureolytic mutant of the same strain of Lactobacillus, urea did not appear in the faeces. The ureolysis inhibiting mechanism is thus linked to urease immunization. Finally, if the antigen was composed of a plant urease, urea appeared much more slowly and in smaller quantities than when the antigen contained Lactobacillus urease.

\title{
PRODUCTION D'ACIDES GRAS VOLATILS PAR DES BaCtéries ANAÉRobies STHICTES \\ DANS LE TUBE DIGESTIF DE SOURIS « GNOTOXÉNIQUES ». EFFET INHIBITEUR SUR « SHIGELLA FLEXNERI »
}

M. RIOTTOT, R. DUCluzeaU*, P. RAIBAUD*, A. PERROT** et M. C. MYNARD

\author{
Groupe des Laboratoires de Gif sur Yvette, \\ C. N. R. S. 91 - Gif sur Yvette \\ * Laboratoire d'Écologie microbienne, \\ Centre national de Recherches zootechniques, I. N. R. A., \\ 78350 Jouy en Josas \\ ** Institut A. Merieux, 254, rue Marcel Mérieux, \\ 69 Lyon $(7 \mathrm{e})$
}

On a ensemencé dans le tube digestif de souris axéniques diverses souches de bactéries anaérobies strictes, productrices in vitro d'acides gras volatils (AGV), ou divers mélanges bactériens provenant de la microflore d'animaux holoxéniques. On a ensuite mesuré la production in vivo d'AGV dans le cæcum ou les fèces de ces animaux gnotoxéniques et on a étudié l'effet inhibiteur des AGV ainsi produits sur une couche de Shigella flexneri.

Nous avons constaté qu'il y a peu de relation entre la production d'AGV in vitro par des souches bactériennes et les concentrations d'AGV présentes dans le cæcum des animaux ensemencés avec des souches in vivo. Certaines souches seulement sont de bonnes productrices d'AGV et si l'on cumule dans un même animal des souches faibles productrices on n'additionne pas leurs productions. Des concentrations cæcales et fécales d'AGV du même ordre que celles que l'on mesure chez les holoxéniques, n'ont été obtenues qu'avec des gnotoxéniques hébergeant un mélange complexe de souches anaérobies strictes thermorésistantes non identifiées.

Chez ces animaux "gnotoxéniques ", on observe en fonction du temps des variations énormes des concentrations cæcales et fécales d'AGV. Ces variations sont même supérieures à ce qu'elles sont chez les holoxéniques. La teneur maximum en AGV dans le cæcum d'animaux gnotoxéniques peut parfois s'observer plusieurs semaines après l'établissement des souches productrices et l'addition de lactose au régime n'influe pas sur la production de ces AGV.

Enfin, on peut affirmer que la corrélation entre la production d'AGV et l'élimination de S. flexneri est très faible. Cette souche est en effet éliminée très efficacement par une flore complexe avant toute production importante d'AGV dans le cæcum alors qu'une autre flore, forte productrice d'AGV quelques semaines après l'ensemencement, n'a qu'un effet antagoniste très limité. 


\title{
SUMMARY
}

\section{PRODUCTION OF VOLATILE FATTY ACIDS BY STRICTLY ANAEROBIC BACTERIA \\ IN THE DIGESTIVE TRACT OF " GNOTOXENIC " MICE. INHIBITORY EFFECT ON SHIGELLA FLEXNERI}

Various strains of strictly anaerobic bacteria producing volatile fatty acids (VFA) in vitro, or various bacterial mixtures from the microflora of holoxenic animals, were implanted in the digestive tract of axenic mice.

The in vivo production of VFA was then measured in the cæcum or the faeces of these "gnotoxenic " animals, and we studied the inhibitory effect of the VFA thus produced on a strain of Shigella fexneri.

There is little relationship between in vitro VFA production by bacterial strains and VFA concentrations present in the cæcum of animals implanted with these strains in vivo. Only some strains are good producers of VFA, and if weak VFA producing strains are accumulated in the same animal, their productions are not additive. Caecal and faecal concentrations of VFA of the same order as those measured in holoxenics were only obtained with gnotoxenics carrying a complex mixture of unidentified strictly heat-resistent anaerobic strains.

In those "gnotoxenic " animals, there were large variations of caecal and faecal VFA concentrations in relation to time. These variations were even higher than those in the holoxenics. The maximum amount of VFA in the caecum of gnotoxenic animals may sometimes be observed several weeks after establishment of the producer strains, and the addition of lactose to the diet did not affect the production of these VFA.

Finally, the correlation between VFA production and the elimination of S. flexneri is very low. This strain is very efficiently eliminated by a complex flora before any large VFA production in the caecum, while another flora producing a high amount of VFA several weeks after implantation, has only a very limited antagonistic effect.

\section{UTILISATION DE LAzOTE ET DES ACIDES AMINÉS CHEZ LE RAT AXENIQUE}

\author{
Étiennette COMBE \\ Station d'Études des Métabolismes, \\ Centre de Recherches de Clermont Ferrand, I. N. R. A., \\ Theix 63110 Beaumont
}

Nous utilisons le rat axénique comme animal expérimental dans l'étude de l'influence de la flore digestive dans la digestion de l'azote. L'expérience que nous relatons ici concerne 8 rats axéniques et to rats holoxéniques (de souche Fischer du service des animaux sans germes du C. N. R. S. de Gif). Ces animaux ont été placés en cage à bilan individuelle. Pendant deux périodes consécutives de 5 et 6 jours les mesures de consommation de l'aliment ( $L 356$ stérilisé à la vapeur), la récolte de l'urine et des fèces, le poids individuel des animaux furent assurés quotidiennement. Les teneurs en azote et en acides aminés furent déterminées sur les échantillons d'aliment, urine et fèces groupés par période. Le poids moyen des rats axéniques et holoxéniques 